\title{
Adult stem cells in the healing of fractures and bone grafts
}

\section{Células-madre adultas en la cicatrización de fracturas e injertos óseos}

\author{
Gabriele Maria Callegaro S1*Ph.D, Saulo Tadeu LPF² Ph.D, \\ Renato do Nascimento L3 M.Sc, Ney Luis Pippi² Ph.D.
}

\begin{abstract}
${ }^{1}$ Regional University of Northwestern State of Rio Grande do Sul, College of Veterinary Medicine, Department of Agrarian Studies. Rua do Comércio 3000, Ijuí-RS, Brazil. 'Federal University of Santa Maria, College of Veterinary Medicine, Laboratory of Experimental Surgery, Avenida Roraima 1000, Santa Maria, RS, Brazil. 3University of Passo Fundo, College of Veterinary Medicine, Integrated Residency in Veterinary Medicine, Rodovia BR 285, Km 292,7, S/n - São José, Passo Fundo-RS, Brazil *Correspondence: gabrieleserafini@yahoo.com.br
\end{abstract}

Received: February 2017; Accepted: October 2017.

\begin{abstract}
The traumatic accidents which result in fractures and even in impairment of a bone segment have a high prevalence in routine veterinary surgery. Many times these fractures are complex and difficulty healing or need bone grafts to preserve and restore the length of the affected limb. Thus, the recovery time of these animals is usually delicate and long, with complications risks, such as delayed union and non-union of the fractured bone segments or absence of graft incorporation. In this sense, the stem cells (SC) have shown to be a strong ally of the orthopedic doctors due to their capacity to provide osteoprogenitor cells, to increase the osteoinductive effect minimize the healing time and provide a greater efficiency to the repairing process. Due to that, before the expectation of their assignments, this review aims to describe the stem cells characteristics, their current applications in the fractures healing and, especially, their contribution to the bone grafts consolidation.
\end{abstract}

Keywords: Mesenchymal stem cells, bone tissue, cell therapy, bone transplantation (Source: MeSH).

\section{RESUMEN}

Los accidentes traumáticos que resultan en fracturas y hasta en el comprometimiento de un segmento óseo tienen alta prevalencia en la rutina quirúrgica veterinaria. Muchas veces esas fracturas son complejas y presentan dificultades de cicatrización o necesitan de injertos óseos para preservar y restaurar el largo del miembro acometido. De esa forma, el tiempo de recuperación de esos animales suele ser delicado y prolongado con riegos de complicaciones, como unión retardada y no unión de los segmentos óseos fracturados o ausencia de incorporación de los injertos. En este sentido, las células-madre (CT) vienen demostrando ser una fuerte aliada de los ortopedistas debido a su capacidad en proveer células osteoprogenitoras, de incrementar el efecto osteoinductor, minimizar el tiempo de cicatrización y proporcionar mayor eficiencia al proceso reparador. Frente a la expectativa de sus atribuciones, la presente revisión tiene por objetivo describir las características de las célulasmadre, sus aplicaciones actuales en la cicatrización de fracturas y, especialmente, su contribución en la consolidación de injertos óseos.

Palabras clave: Células-madre mesenquimales, tejido óseo, terapia celular, trasplante óseo (Fuente: MeSH). 


\section{INTRODUCTION}

The principle of cellular therapy consists of repairing the damaged tissues or organs with the replacement of non-functional cells for normal cells. The SCs present in the organism, naturally, perform this function, therefore, when the lesions are more extensive, the SCs are not capable of correcting them and the disease is established. Under such situations, the cell therapy with those cells aims at enhancing the natural correction mechanism, concentrating them at the injury site so that they can act more effectively (1). With the advances in medicine, nowadays it is now possible to collect, cultivate and REINFUNDIR the stem cells with therapeutic purpose, forming different tissues, such as bone, liver, and neural (2).

Among the cell therapy options as an adjuvant to the osseous healing, the use of stem cells has been recommended, especially, the mesenchymal stem cells (MSC) by presenting a higher plasticity and bioavailability than the other SC cells. It is expected that these cells, under pathological conditions, help the body overcome the lack of osteoprogenitor source of the other cells involved with the repair and soluble factors for the recruitment of new cell types (3).

In certain types of fractures, the bone grafts, many times are indicated for replacement of a total bone segment. Depending on the type of graft chosen, its function will be a mechanic support and osteoconduction. Thus, the incorporation time is delayed and with complications risk (4).

In the cortical graft the incorporation starts more by the osteoclasts, where the same is revascularized, reabsorbed and replaced slowly by host tissue, with the graft by acting as a support for the formation of new bone. During this resorption phase, the graft is weakened and predisposed to catastrophic failure (4). Its resistance can only be from $50 \%$ to $60 \%$ of the original in approximately 12 months after transplantation, and sometimes only recovered two to three years after the grafting (5).

In this context, the MSC are currently very researched as a therapeutic alternative in bone grafts, due to their high osteoinduction capacity, i.e., differentiation into osteogenic cells, and their effectiveness in bone recovery is proven (6). This review aims to describe the stem cells characteristics, their current applications in the fractures healing and, especially, their contribution to the bone grafts consolidation.

\section{INTRODUCCIÓN}

El principio de la terapia celular consiste en reparar tejidos u órganos dagnificados con la sustitución de las células no funcionales por células normales. Las CT presentes en el organismo, de forma natural, ejercen esa función; sin embargo, cuando las lesiones son más extensas, las CT no son capaces de corregirlas y la enfermedad se establece. En esas situaciones, la terapia celular con estas células tiene como objetivo potencializar el mecanismo natural de corrección, concentrando las mismas en el local de la lesión para que puedan actuar más eficientemente (1). Con los avances en la medicina, hoy es posible colectar, cultivar y re-infundir las células-madre con finalidad terapéutica, formando diversos tejidos, como óseo, hepático, neural y adiposo (2).

Entre las opciones de terapia celular como adyuvante de la cicatrización ósea, ha sido preconizado el uso de células-madre sobre todo las células-madre mesenquimales (CTM), por presentar mayor plasticidad y biodisponibilidad que las demás CT adultas. Se espera que estas células, bajo condiciones patológicas, auxilien al organismo a superar la falta de fuente osteoprogenitora de las otras células comprometidas con la reparación y de factores solubles para el reclutamiento de nuevos tipos celulares (3).

En ciertos tipos de fracturas, los injertos óseos, muchas veces son indicados para la sustitución de un segmento óseo total. Dependiendo del tipo de injerto elegido, su función principal será de soporte mecánico y osteoconducción. De esa forma, el tiempo de incorporación es demorado y con riesgo de complicaciones (4).

En los injertos corticales la incorporación se inicia por parte de los osteoclatos, donde el mismo es revascularizado, reabsorbido y sustituido por el tejido del hospedero lentamente, con el injerto actuando como un soporte para la formación de hueso nuevo. Durante esa fase de reabsorción, el injerto se encuentra debilitado y predispuesto a falla catastrófica (4). Su resistencia puede ser solamente de $50 \%$ a $60 \%$ de la original, en aproximadamente, 12 meses tras el trasplante y algunas veces, solamente recuperada dos a tres años tras el injerto (5).

En ese ámbito, las CTM son actualmente muy investigadas como alternativa terapéutica en injertos óseos, debido a su alta capacidad de osteoinducción (diferenciación en células osteogénicas); siendo su eficacia comprobada en la recuperación ósea (6). La presente revisión 
Stem cells (SC) characteristics. The stem cells differ from other organism cells because they are undifferentiated or not specialized and because they have the ability to generate not only new SC, but also, under certain physiological conditions and experiential, specialized cells with different functions (7).

The SCs can be divided as to their nature in embryonic or adult cells. The embryonic cells are found in the internal cell mass of the blastocyst (embryo). These cells when separated and placed in appropriate conditions are able to cause any of the multiple cell types of an individual. As they are capable of forming a complete body, they are called Pluripotent. The adult SCs are found in any individual after the blastocyst phase. Several tissues (or perhaps all of them) have stem cells, which constitute a reserve from which the organism uses to replace cells that die by apoptosis or lesions caused by wounds or disease. However, in general, the adult $\mathrm{SCs}$ are infrequent and their identification is difficult, because they do not have morphological characteristics or others that distinguish them from other cells of that organ (1).

Some types of adult SCs have different degrees of plasticity, ranging from very low as the epithelial SCs, to the very high as the MSCs. The capacity that the MSCs have to originate the most varied of cell a type makes them very interesting for use in cell therapy (1).

The MSCs plasticity mechanisms are not fully understood yet. There are two theories proposed to describe for their differentiation capacity. One of them is the transdifferentiation in which the cell would alter its gene expression to a cellular lineage totally different, resulting in distinct cell types. The transdifferentiation can occur directly, when the cell changes its cytoskeleton and its protein synthesis to redifferentiate into another specific or indirect cell type, when they dedifferentiate in a more primitive stem for, later redifferentiate into another cell type. Another theory proposed is the cell differentiation through fusion. Through this theory the MSCs would be able to merge to an adult-target cell, assuming the gene expression standard of the adult to which it merged. In addition, the MSCs secrete a variety of chemokines, besides expressing receptors for cytokines and growth factors. Therefore, such cells interact with resident cells (niche) and they may induce them, by a paracrine mechanism, to differentiate in distinct lineage cells, according to this signalization (8).

Not only the embryonic cells but also the adult ones are potential application sources. However, tiene el objetivo de describir las características de las células-madre, sus aplicaciones actuales en la cicatrización de fracturas y enfatizar su contribución en la consolidación de injertos óseos.

Características de las células-madre (CT). Las células-madre se distinguen de otras células del organismo por ser indiferenciadas o no especializadas y por tener la capacidad de generar nuevas CT y células especializadas con diferentes funciones (7); estas ultimas bajo ciertas condiciones fisiológicas y experimentales.

Las CT pueden ser divididas en cuanto a su naturaleza en embrionarias o adultas. Las embrionarias son encontradas en la masa celular interna del blastocisto (embrión). Tales células cuando son separadas e implantadas en condiciones apropiadas son capaces de originar cualquiera de los múltiples tipos celulares de un individuo. Como ellas son capaces de formar un organismo completo, son llamadas de pluripotentes. Las CT adultas son encontradas en cualquier individuo después de la fase de blastocisto. Diversos tejidos (o quizás todos) tienen células-madre, que constituyen una reserva, que el organismo utiliza para sustituir las células que murieron por apoptosis o lesiones por heridas o enfermedades. Sin embargo, de modo general, las CT adultas son poco frecuentes y su identificación es difícil, pues no presentan características morfológicas u otras que la distingan de las otras células de los órganos (1).

Algunos tipos de CT adultas presentan diferentes grados de plasticidad, desde muy bajos como las CT epiteliales, hasta muy altos como las CTM. La capacidad que las CTM pueden originar tipos celulares más variados que las hacen muy interesantes para su uso en terapia celular (1).

Los mecanismos de plasticidad de las CTM todavía no son completamente comprendidos. Hay dos teorías propuestas para describir su capacidad de diferenciación. Uno de ellos es la transdiferenciación, en la cual la célula alteraría su expresión génica hacia la de un linaje celular totalmente diferente, originándose tipos celulares distintos. La transdiferenciación puede ocurrir de forma directa, cuando la célula cambia su citoesqueleto y su síntesis proteica para rediferenciarse en otro tipo celular específico, o indirecta, cuando la célula se diferencia en una célula-madre más primitiva para, posteriormente, rediferenciarse en otro tipo celular. La otra teoría propuesta es la diferenciación celular por la fusión. A través de esa teoría, las CTM serían capaces de fusionarse a una célula adultodestino, asumiendo el estándar de expresión 
due to the practical difficulties of obtaining embryonic SCs arising from ethical, moral and legal aspects, it has been prioritized the use of adult SCs (9).

Before this, studies have been carried out with the objective to induce the pluripotency characteristic to adult SCs. For this reason, researchers have managed to extend the differentiation potential of these cells, by means of nuclear somatic transfer and genetic reprogramming of somatic cells to the embryonic state, through the introduction of determining pluripotency genes (OCT-4, SOX-2, KLF-4, cMYC). These cells are called induced pluripotent stem cells or IPs cells and have a greater capacity of plasticity that the adult SCs found in the body (7).

Mononuclear stem cells and mesenchymal stem cells. The adult SCs can be obtained from bone marrow (BM), peripheral blood, umbilical cord, fetal liver, neural tissue or other various mesenchymal tissues from adult individual, such as synovia, periosteum, muscle tissue or adipose tissue (2).

For many years, the BM was considered the main source of stem cells for applications with stem cell therapy (10). In there exist at least two populations of progenitor stem cells: the hematopoietic progenitor cells (which give rise to blood cells) and mesenchymal progenitor cells (which give rise to the muscle cells, adipose tissue, hepatocytes, osteocytes, chondrocytes and stroma). Both the hematopoietic cells, and the mesenchymal cells are considered to be the mononuclear portion of the BM cells. It is important to emphasize that the MSCs represent a small fraction $(0.001-0.01 \%$ of the total population of nucleated cells of the BM (11).

So, after collecting the blood from the marrow, the same can be applied directly to the patient (9), centrifuged to obtain mononuclear portion (12) or undergo isolation and expansion in culture (9).

The authors of this review agree that all applications are beneficial, but at the moment that it is applied only the material newly collected from the BM, the concentration of mononuclear stem cells is very low, because this material will also have the blood mature cells, lymphocytes, fragments of stroma and fat. When the blood is centrifuged only to obtain the mononuclear fraction, that is, the hematopoietic and mesenchymal SCs together, it is enhanced a little more the quality of the material applied. However, the option suggested by the authors is, whenever possible, to carry out expansion génica de la célula adulta a la cual se ha unido. Además, las CTM secretan una gran variedad de quimiocinas, y también expresan receptores para citocinas y factores de crecimiento. De esa forma, tales células interactuan con las células residentes (nicho) y pueden inducirlas, por mecanismo paracrino, a diferenciarse en linajes celulares distintos, de acuerdo con esa señalización (8).

Tanto las CT embrionarias como las adultas son fuentes potenciales de aplicación. Sin embargo, debido a las dificultades prácticas de obtención de CT embrionarias decurrentes de aspectos éticos, morales y legales, se ha priorizado el uso de las CT adultas (9).

Frente a eso, estudios vienen siendo realizados con el objetivo de inducir la característica de pluripotencia en CT adultas. Para eso, investigadores lograran ampliar el potencial de diferenciación de esas células, por medio de la transferencia nuclear somática y reprogramación genética de células somáticas al estadio embrionario, mediante la introducción de genes determinantes de plenipotencia (OCT-4, SOX-2, $\mathrm{KLF}-4, \mathrm{cMYC}$ ). Esas células son denominadas células-madre pluripotentes inducidas o IPs cells y tienen una capacidad mayor de plasticidad que las CT adultas encontradas en el organismo (7).

Células-madre mononucleares y célulasmadre mesenquimales. Las CT adultas pueden ser obtenidas a través de medula ósea (MO), sangre periférica, cordón umbilical, hígado fetal, tejido neural u otros diversos tejidos mesenquimales del individuo adulto, tales como sinovia, perióstio, tejido muscular o tejido adiposo (2).

Por muchos años, la MO fue considerada la principal fuente de células-madre para aplicaciones con terapia celular (10). En ella existen, por lo menos, dos poblaciones de células-madre progenitoras: las células progenitoras hematopoyéticas (que originan las células sanguíneas) y las células progenitoras mesenquimales (que originan a las células musculares, del tejido adiposo, hepáticos, osteocitos, condrocitos y estroma). Tanto las hematopoyéticas, como las mesenquimales son consideradas la porción mononuclear de las células de la MO. Es importante enfatizar que las CTM representan una pequeña fracción (0.001$0.01 \%$ ) de la población total de células nucleadas de la MO (11).

Siendo así, tras colectar la sangre de la medula, la misma puede ser aplicada directamente al paciente (9), centrifugado para la obtención de 
in culture, because through this procedure it is possible to obtain only the desired lineage of cells in a higher concentration.

In the bone healing several studies report the use of allogeneic and autogenous MSCs. Usually, in these studies, it is used not only the mononuclear fraction of BM, but also the culture expanded of MSCs obtained from various organs. Both can be applied at the injury site, either separately or combined with bone substitutes and biomaterials or by intravenous infusion (3).

Currently, the adipose tissue has been gaining notoriety as being an alternative for obtaining MSC, because in addition to being easily collected in little painful places and in large quantities, studies have shown equal differentiation ability into the tissues of mesodermal origin when compared to the MSC of BM. In this sense, the adipose tissue gains some advantage, since the collection in BM is painful and offers low yield of collected cells (13)

When using the adipose tissue as a SC source it is possible to apply the stromal vascular fraction (SVF) (14), which contains a heterogeneous population of cells including circulating blood cells, fibroblasts, PERIÓCITOS and endothelial cells, in addition to the adult SCs; or the SVF can be expanded in culture for obtaining the MSC (7). At the moment, the adipose tissue has been the most explored to MSC collection in the laboratory of cell therapy (LATECER) from our institution (Federal University of Santa Maria, Santa Maria, RS, Brazil.

Although the MSC collection form favors its autogenous use, the possibility of allogenic treatment allows the creation of MSC databases, extending the therapeutic possibilities. Patients in morbid unfavorable conditions could make use of cell cultures already established (3). In LATECER we have been carrying out MSCs cultures derived from adipose tissue (ADSCs) (Figure 1) and subsequent application in animals, allogeneically, obtaining good therapeutic results and not observing reactions of rejection by the animals receiving the cell grafting.

The MSCS embryonic origin is the mesodermal, they arise from mesenchymal cells that give rise to connective tissues such as bone, cartilage, fat, as well as the vascular system and hematopoietic (15). Therefore, they can be found in small quantities in perivascular regions of all the adult tissues, including BM, the adipose tissue, the periosteum, muscle tissue and the parenchymal organs (10). Regardless of the source of obtaining, the biological studies show great similarity among these cells (16). la porción mononuclear (12) o sufrir aislamiento y expansión en cultivo (9).

Los autores de esta revisión concuerdan que todas las aplicaciones son benéficas, pero al momento en que se aplica el material reciéncolectado de la $\mathrm{MO}$, la concentración de célulasmadre mononucleares es muy baja, pues en ese material también se encontrarán las células maduras de la sangre, linfocitos, fragmentos de estroma y grasa. Cuando se centrifuga la sangre a fin de obtener solamente la fracción mononuclear (CT hematopoyéticas y mesenquimales), se mejora la calidad del material aplicado. Sin embargo, la opción sugerida por los autores es realizar la expansión en cultivo (siempre que sea posible), pues a través de ese procedimiento se puede obtener solamente el linaje deseado de células en una concentración más alta.

En la cicatrización ósea diversos estudios reportan el uso de las CTM alógenas y autógenas. Usualmente, en esos estudios, se emplea desde la fracción mononuclear de la $\mathrm{MO}$, hasta el cultivo expandido de CTM obtenidas de diversos órganos. Ambas pueden ser aplicadas localmente en la lesión, aisladamente o combinadas con sustitutos óseos y biomateriales o por infusión intravenosa (3).

Actualmente, el tejido adiposo viene ganando notoriedad como alternativa para la obtención de CTM, pues además, de ser fácilmente colectado, estudios muestran igual capacidad de diferenciación en tejidos de origen mesodérmico cuando son comparadas con las CTM de la MO. En este sentido, el tejido adiposo gana alguna ventaja, puesto que la colecta en la MO es dolorosa y produce un bajo rendimiento de las células colectadas (13).

Al utilizar el tejido adiposo como fuente de CT es posible aplicar la fracción vascular estromal (FVE), (14), que contiene una población heterogénea de células, incluyendo células sanguíneas circulantes, fibroblastos, periocitos y células endoteliales, además, de las CT adultas. La FVE también puede ser expandida en cultivo para la obtención de las CTM (7). Hasta el momento, el tejido adiposo ha sido el más explorado para colecta de CTM en el laboratorio de terapia celular (LATECER) de nuestra institución (Universidade Federal de Santa Maria, Santa Maria-RS, Brasil).

Aunque la forma de colecta de CTM favorezca su uso autógeno, la posibilidad de tratamiento alógeno permite la creación de bancos de CTM, ampliando las posibilidades terapéuticas. Pacientes en estados mórbidos desfavorables podrían hacer uso de cultivos celulares ya establecidos (3). 


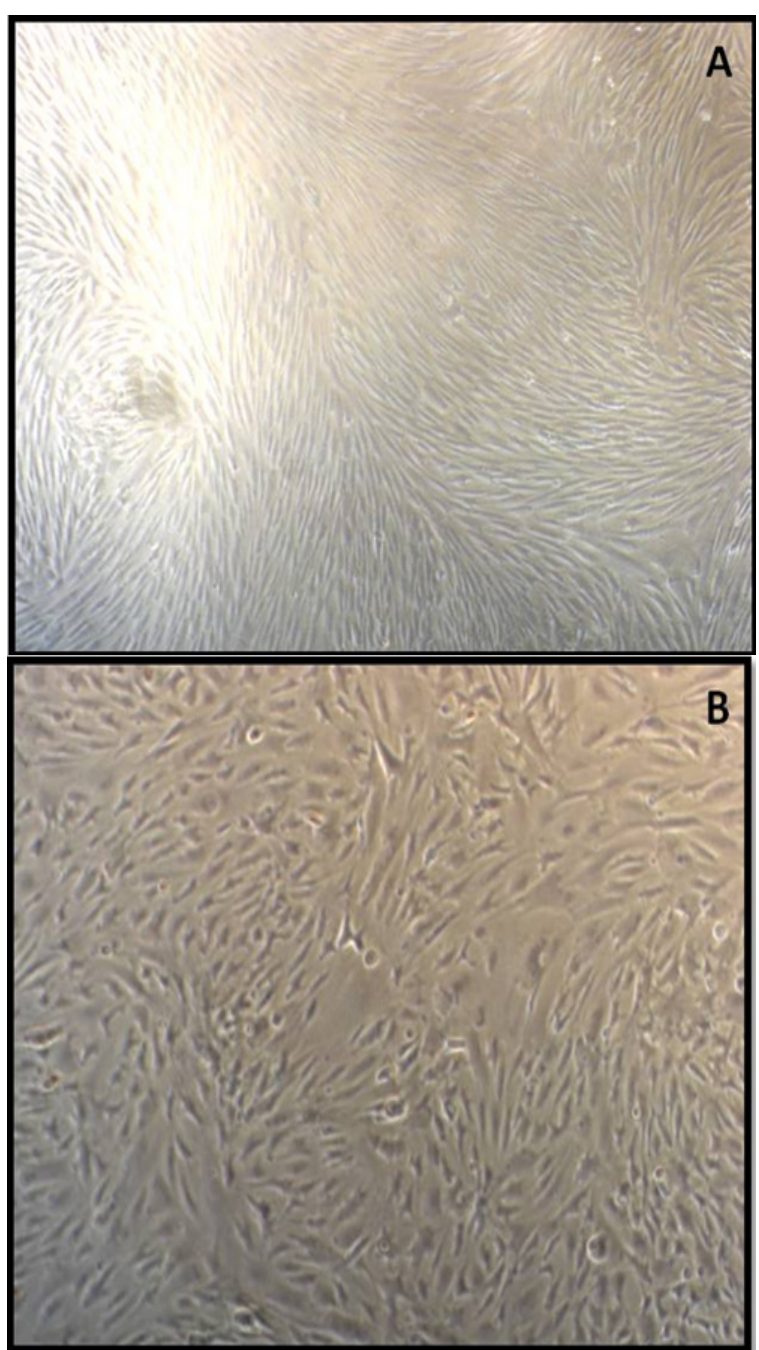

Figure 1. Source: Authors' personal files. MSCs derived from rabbits' adipose tissues. (A) ADSCs from interscapular adipose tissue at 21 days of cultivation in laboratory. (B) ADSCs from inter renal adipose tissue at 21 days of cultivation.

For a population of cells be classified as MSC it is necessary for them to be able to adhere to plastic when grown; that the expressions CD105, CD73 and CD90 be present, and that CD34, CD45, CD14 or CD11b, CD79 or CD19 and HLA-DR are not expressed in more than $95 \%$ of cells in culture (17); and that these cells are able to differentiate and give rise to osteoblasts, chondroblasts, hepatocytes, neurons, epithelial cells, renal and cardiac, among others (10). Their high plasticity provides therapeutic promising perspectives, becoming a focus of research around the world (3).

The employment of ADSCs has been considered in the treatment of chronic degenerative diseases, such as in muscular dystrophy linked to the $X$
En el LATECER se están realizando cultivos celulares de CTM derivadas del tejido adiposo (ADSCs), (Figura 1) para la posterior aplicación en animales, de manera alógena, obteniendo buenos resultados terapéuticos y no observando reacciones de rechazo por los receptores del injerto celular.

El origen embrionario de las CTM es mesodermal, ellas surgen a partir de células mesenquimales que dan origen a tejidos conjuntivos, como huesos, cartílagos, grasa, como el sistema vascular y hematopoyético (15). Por lo tanto, pueden ser encontradas en pequeñas cantidades en regiones perivasculares de todos los tejidos adultos, incluyendo la MO, el tejido adiposo, el perióstio, el tejido muscular y los órganos parenquimatosos (10). Independientemente de la fuente de obtención, los estudios biológicos muestran gran similitud entre esas células (16).

Para que una población de células sea clasificada como CTM deben ser capaces de adherirse al plástico cuando son cultivadas; que haya expresión de CD105, CD73 y CD90 y que CD34, CD45, CD14, o CD11b, CD79 o CD19 y HLA-DR no sean expresados en más de $95 \%$ de las células en cultivo (17), así como que estas células sean capaces de diferenciarse y dar origen a osteoblastos, condroblastos, hepatocitos, neuronas, células epiteliales, renales y cardíacas, entre otras (10). Su alta plasticidad provee perspectivas terapéuticas promisorias, tornándose foco de pesquisas en todo el mundo (3).

El empleo de las ADSCs ha sido utilizado en el tratamiento de enfermedades crónicas degenerativas, como en la distrofia muscular relacionada al cromosoma $X$ de ratones, además, de ser promisoria para los tratamientos quirúrgicos reconstructivos, de origen traumática o no, como en las lipoatrofias congénitas o adquiridas (7). En equinos, muchos estudios ya demostraron su acción benéfica en el tratamiento en tendinitis y enfermedades articulares (15).

En 2011 un estudio evaluó el trasplante de la fracción total de células mononucleares de la medula ósea y de la fracción vascular estromal del tejido adiposo, asociado al uso de la membrana celulósica, en heridas cutáneas de conejos. El grupo A no recibió tratamiento, el grupo B recibió solamente membrana celulósica y los grupos $C$ y $D$, además, de la membrana, también fueron sometidos a trasplante autólogo de la fracción total de células mononucleares o de la fracción vascular estromal. Al final del período de evaluación, los tres grupos tratados presentaron diferencia estadísticamente significativas en el área de la herida en relación al grupo control. El 
chromosome of mice, besides being promising for the reconstructive surgical treatments of traumatic origin or not, as in lipoatrophy, congenital or acquired (7). In horses, many studies have already shown their beneficial action in dealing with tendonitis and joints infirmities (15).

In 2011 a study evaluated the transplantation of the total fraction of bone marrow mononuclear cells and the stromal vascular fraction of adipose tissue, associated with the use of cellulose membrane, in rabbits' skin wounds. Group A received no treatment, Group B received only cellulose membrane and the groups $C$ and $D$, in addition to the membrane, were also subjected to autologous transplantation of total mononuclear cells or stromal vascular fraction. At the end of the evaluation period, the three treated groups presented statistically significant differences in the wound area compared to the control group. The group that received the stromal vascular fraction from adipose tissue showed the lowest time of wound healing (18).

Performance and identification of mesenchymal stem cells. The MSCs have migratory behavior, i.e., they are able to reach the ill place after the intravenous, intralesional, or perilesional application routes. The cytokines released in sites of inflammation or injury promotes the chemical signals to guide the implanted cells migration. These cells migrate selectively to areas of injury, inflammation and tumors, being involved in tissue repair and formation of stroma associated with the tumor. The MSCs are capable of self-regulating the inflammation cascade factors, including pro-inflammatory cytokines, interleukin- $1 \beta$, tumor necrosis factor- $a$ and Interferon- $\gamma$. These anti-inflammatory effects can have profound influences on the local tissue site and also influence the researchers' ability to use allogeneic stem cells without inducing a host's immune response (15).

Moreover, these cells also secrete growth factors that promote the effective tissue revascularization, besides presenting antiapoptotic effect, important in the restoration and maintenance of tissue function. Studies have shown that the progenitor stem cells, particularly those derived from bone marrow, promote tissue repair through secretion of factors that increase the regeneration of damaged cells, as well as stimulate the proliferation and differentiation of endogenous stem cells in different tissues and reduce the inflammatory and immune reactions (15). grupo que recibió la fracción vascular estroma del tejido adiposo presentó el menor tiempo de cicatrización de la herida (18).

Actuación e identificación de las célulasmadre mesenquimales. Las CTM tienen comportamiento migratorio, o sea, son capaces de llegar hasta el local enfermo tras la aplicación por vía intravenosa, intralesión o perilesión. Las citocinas liberadas en los locales de inflamación - lesión promueven la señalización química para orientar la migración de las células implantadas. Esas células migran selectivamente para áreas de lesión, inflamación y tumores, estando envueltas en la reparación de tejido y formación del estroma asociado al tumor. Las CTM son capaces de autorregular los factores de la cascada de la inflamación, incluyendo las citocinas pro-inflamatorias interleucinas $-1 \beta$, factor de necrosis tumoral-a e interferon- $\gamma$. Estos efectos antiinflamatorios pueden tener influencias profundas en el ambiente de tejido local e igualmente influenciar a la habilidad de investigadores en utilizar células-madre alogénicas sin inducir una respuesta inmune del hospedero (15).

Además, esas células también secretan factores de crecimiento que promueven la revascularización efectiva del tejido, presentan efecto antiapoptótico, importante en la restauración y mantenimiento de la función del tejido. Estudios revelaron que las células-madre progenitoras, particularmente las derivadas de la medula ósea, promueven reparación de tejido mediante secreción de factores que aumentan la regeneración de las células lesionadas y estimulan la proliferación y diferenciación de células-madre endógenas en diversos tejidos y reducen las reacciones inflamatorias e inmunes (15).

Marcadores de superficie celular son moléculas bioactivas introducidas o adjuntas a la superficie externa de todas las células. Estas moléculas funcionan como receptores, permitiendo que las células se comuniquen unas con las otras o se adhieran específicamente a determinadas estructuras biológicas o celulares. Estas moléculas que reflejan la función celular pueden también ser utilizadas para inducir efecto de marcación e identificación de tipos celulares particulares, incluyendo las células-madre. La designación "Cluster of differentiation" (CD) se refiere a los marcadores de superficie celular utilizados para caracterizar tipos celulares. Hasta el momento, ningún marcador $C D$ fue encontrado para identificar definitivamente las CTM siendo necesario, una combinación de marcadores para la caracterización de una población homogénea (15). 
Markers of cell surface are bioactive molecules introduced or situated at the outside surface of all cells. These molecules act as receptors, allowing the cells to communicate with each other or bind specifically to certain biological or cellular structures. These molecules that reflect the cellular function can also be used for the marking and identification purpose of specific cell types, including the stem cells. The designation "cluster of differentiation" (CD) refers to markers of cell surface used to characterize cell types. So far no marker was found to identify definitely the MSC being necessary, a combination of markers for characterization of a homogeneous population (15).

The variable expression of many of the lineage markers can be due not only to the different methods of cellular isolation and culture characteristics, but also to the variation in the tissue origin and the various species (17). The lack of a specific marker that sets the MSCs emphasizes their identification based on identification of a set of surface markers and in their ability to differentiate into adipocytes, chondrocytes and osteocytes (16).

The MSC in the presence of beta-glycerol phosphate, ascorbic acid, dexamethasone and bovine fetal serum acquire the morphology of osteoblasts. The chondrogenic differentiation requires that the MSCs be grown in tridimensional environment and in medium with low concentrations of fetal bovine serum and in the presence of TGF-a. The adipogenic differentiation requires a monolayer cell grown in the presence of isobutylmethylxanthine. For differentiation in myocytes it is indispensable the presence of 5-azacytidine (16).

The MSCs are capable of differentiating also in vascular cells or contribute for the formation of blood vessels in the adult individual. It was reported that the MSC, after direct injection into the heart, have the ability to differentiate into cells with endothelial phenotype, cardiomyocytes, vascular pericytes and smooth muscle cells. As seen above, the MSCs can differentiate into cells of various tissues, although the mechanisms that participate in these processes are not fully known (16).

Stem cells as adjuvant in the healing of fractures. The bone healing has three phases: inflammation, in which there is the infiltration of leukocytes that determine the chemotaxis of mesenchymal cells and fibroblasts that will differentiate into osteoblasts; reparation, in which we have the formation of soft callus (loose connective tissue and fibroblasts) and then the
La expresión variable de muchos de los marcadores de linaje puede ser debido no solamente a los diferentes métodos de aislamiento celular y características del cultivo, sino también a la variación en el origen del tejido y a las diferentes especies (17). La falta de un marcador específico que defina las CTM valoriza su identificación con base en la identificación de un conjunto de marcadores de superficie y en su capacidad de diferenciación en adipocitos, condrocitos y osteocitos (16).

Las CTM en presencia de beta-glicerol fosfato, ácido ascórbico, dexametasona y suero fetal bovino adquieren la morfología de osteoblastos. La diferenciación condrogénica necesita que las CTM sean cultivadas en ambiente tridimensional y en medio con bajas concentraciones de suero fetal bovino y en presencia de TGF-a. La diferenciación adipogénica requiere una monocapa celular cultivada en presencia de isobutilmetilxantina. Para la diferenciación en miocitos es imprescindible la presencia de 5-azacitidina (16).

Las CRM son capaces de diferenciarse también en células vasculares o contribuir para la formación de vasos sanguíneos en el individuo adulto. Fue reportado que las CTM, tras inyección directa en el corazón, tienen capacidad de diferenciarse en células con fenotipos endotelial, cardiomiocitos, pericitos vasculares y células musculares lisas. Como fue visto anteriormente, las CTM pueden diferenciarse en células de varios tejidos, aunque los mecanismos que participan de ese proceso no son totalmente conocidos (16).

Células-madre como adyuvantes en la cicatrización de fracturas. La cicatrización ósea tiene tres fases: inflamación, en la cual existe la infiltración de leucocitos que determinan la quimiotaxis de células mesenquimales y fibroblastos que se diferenciarán en osteoblastos; reparación, en la cual tenemos la formación de un callo blando (tejido conjuntivo débilfibroblastos) y, en seguida, el callo duro (tejido óseo inmaduro); finalmente la remodelación, en la cual se forma el tejido óseo maduro (2).

La base del hueso en formación y en reparación son las CTM, que responden y producen citocinas regenerativas, se replican y se diferencian, forman la matriz estructural y responden a la demanda mecánica para restaurar las funciones del esqueleto (19).

Factores de crecimiento (FC) locales y sistémicos estimulan las CTM a migrar para el foco de fractura a través de la osteoinducción, o se diferencian en condroblastos y osteoblastos 
hard callus (immature bone tissue); and finally remodeling, in which the bone tissue is formed (2).

The base of the bone in formation and in repair are the MSCs, which respond and produce regenerative cytokines, replicate and differentiate themselves, form the structural matrix and respond to the mechanical demand to restore the functions of the skeleton (19).

Local and systemic growth Factors (GF) stimulate the MSCs to migrate to the focus of the fracture and through the osteoinduction, to differentiate into chondroblasts and osteoblasts and thus, form the bone callus. Peptides BMPs and TGF- $\beta$ are the main growth factors responsible for the recruitment and differentiation of MSCs to the bony callus formation and subsequent formation of lamellar bone during the remodeling phase (6).

Among the cell therapy options as an adjuvant to the osseous healing, the use of MSCs has been recommended due to presenting a higher plasticity and bioavailability than the other adult SCs. Bone defects in experimental models treated with MSC have demonstrated that favorable biological and mechanical environments result in proliferation and differentiation of MSC into osteoblasts and chondrocytes, and that the presence of stem cells in experimental bone defects decreases the defect healing time (19).

Researchers have created tibial defects in dogs and treated with three different treatments: Sponge of gelatin soaked in saline solution (G1), sponge of gelatin soaked with inhaled BM processed (G2) and a sponge of gelatin soaked with inhaled BM processed and bone morphogenetic protein (rhBMP-2) (G3). The healing was assessed by radiographic studies, and the presence of mononuclear SCs was identified by means of nanocrystal markers Qtracker, in microscopy with fluorescent light, one week after the surgery. Among the cells identified by the marker, cells of bone lineage were found and the radiographic assessments demonstrate accelerated bone growth in animals of $\mathrm{G} 2$ and $\mathrm{G} 3$. There were significant differences between the $\mathrm{G} 1$ and $\mathrm{G} 3$ in all time periods, and between $\mathrm{G} 1$ and $\mathrm{G} 2$ in 30 and 45 days. The researchers concluded that the adult mononuclear SCs supplemented or not with rhBMP-2 is an alternative for bone growth in experimental acute defects of dogs' tibia (20).

In 2014 a study evaluated the standardization of techniques and the test of association of plateletrich plasma (PRP) and mononuclear SCs. To this end, dogs' tibial defects were performed, in a pilot study, which were filled with six different y con eso, formar el callo óseo. Los péptidos BMPs y TGF- $\beta$ son los principales factores de crecimiento responsables por el reclutamiento y diferenciación de las CTM para la formación del callo duro y posterior formación de hueso lamelar durante la fase de remodelado (6).

Entre las opciones de terapia celular como adyuvante a la cicatrización ósea ha sido preconizada la utilización de CTM por presentar mayor plasticidad y biodisponibilidad que las otras CT adultas (3). Defectos óseos en modelos experimentales tratados con CTM han demostrado que ambientes biológicos y mecánicos favorables resultan en proliferación y diferenciación de CTM en osteoblastos y condrocitos, así como que la presencia de células-madre en defectos óseos experimentales disminuye el tiempo de cicatrización del defecto (19).

Investigadores generaron defectos tibiales en perros y trataron con tres diferentes tratamientos: esponja de gelatina embebida en solución fisiológica (G1), esponja de gelatina embebida con aspirado de MO procesado (G2) y esponja de gelatina embebida con aspirado de MO procesado y proteína ósea morfogenética (rhBMP-2) (G3). La cicatrización fue evaluada por estudios radiográficos, y la presencia de CT mononucleares fue identificada por medio de marcadores nanocristales Qtracker, en microscopía con luz fluorescente, una semana después de la intervención quirúrgica. Entre las células identificadas por el marcador, fueron encontradas células de linaje óseo y las evaluaciones radiográficas demostraron crecimiento óseo acelerado en los animales de G2 y G3. Hubo diferencias significativas entre el $\mathrm{G} 1$ y $\mathrm{G} 3$ en todos los tiempos estudiados, y entre $\mathrm{G} 1$ y $\mathrm{G} 2$ en los tiempos de 30 y 45 días. Los investigadores concluyeron que las CT mononucleares adultas suplementadas o no con rhBMP-2 es una alternativa favorable al crecimiento óseo en defectos experimentales agudos de tibia de perros (20).

En 2014 un estudio evaluó la estandarización de técnicas y la prueba de asociación del Plasma Rico en Plaquetas (PRP) y de las CT mononucleares. Para tal fin, fueron generados defectos tibiales en perros, en un estudio piloto, los cuales fueron llenados con seis diferentes tratamientos. En el perro I, la falla fue rellenada con solución fisiológica; en el II, con PRP; en el III, con la fracción total de las células mononucleares (FTCM); en el IV, con la FVE; en el V, con el PRP asociado a la FTCM; en el VI, con la asociación PRP y FVE. Fueron realizadas evaluaciones clínicas, de los grados de claudicación, radiografías, perimetría del muslo, biomecánica y biopsias. La 
treatments. In dog I, the failure was filled with saline solution; in the second, with PRP; in III, with the total fraction of mononuclear cells (TMCF); in the IV, with the SVF; in V, with the PRP associated to the TMCF; in VI, with the association PRP and SVF. It was carried out clinical evaluations, degrees of lameness, $\mathrm{x}$-rays, perimeter of the thigh, biomechanics and biopsies. The TMCF reached a count and average viability of $2.0 \times 10^{8}$ cells and $90 \%$, respectively, while the SVF achieved $3 \times 10^{6}$ cells and $50 \%$. The PRP concentrated, on average, seven times the initial number of platelets out of the total blood, from 250,000 $\mu \mathrm{l}-1$ platelets in the total blood to $1,750,000 \mu \mathrm{l}-1$ platelets in PRP. The authors obtained adequate standardization of the techniques, enabling the test of association between mononuclear stem cells and PRP, as well as their single use, the repair of cortical bone defects, indicating the possibility of the TMCF association and PRP to be the best treatment (14).

Vaz et al (21) in 2010 applied a centrifuged osteogenic of BM in experimental fractures of rabbits' fibula bone and observed an average increase in bone mineral density of the calluses of $40.3 \%$ and the relative amount of bone tissue in $9.4 \%$, without a significant increase in the relative amounts of cartilage or fibrosis. The author considers that the centrifuged favored bone consolidation with qualitative improvement of bone callus.

Kraus and Kirker-Head (19) in 2006 performed a defect of total segment of $21 \mathrm{~mm}$ on the femur of dogs and fixed with a plate in order to create a model of non-bone union. After 15 days of the creation of the defect, autologous MSCs of BM were collected, isolated and cultured and associated with a cylinder of hydroxyapatite and implanted in the femur. There was a stimulus for bone formation, with formation of new adjacent bone to the implant, infiltrating into the receptor bone.

Barros et al (22) in 2001 treated failures of total segment of rabbits' radius with integral BM or BM centrifuged applied percutaneously. The percutaneous route application proved to be a simple method, with minimal trauma to the tissues, not introducing devitalized tissue and, thus, reducing the risk of infection and interference in bone repair. The radiographic evaluation of the operated limbs, held on the second day of grafting and a week after, demonstrated the efficiency of the application of $\mathrm{BM}$ and its role in bone formation.

Researchers have investigated the healing potential of calcium alginate associated with the
FTCM obtuvo un recuento y viabilidad promedio de $2 \times 10^{8}$ células y $90 \%$, respectivamente, mientras la FVE obtuvo $3 \times 10^{6}$ células y $50 \%$. EI PRP concentró, en promedio, siete veces el número inicial de plaquetas de la sangre total, de $250.000 \mathrm{\mu l}^{-1}$ plaquetas en la sangre total para $1.750 .000 \mathrm{\mu l}^{-1}$ plaquetas en el PRP. Las técnicas estandarizadas, empleadas por los autores permitieron la prueba de asociación entre las células-madre mononucleares y el PRP, así como su uso aislado, en la reparación de fallas óseas corticales, indicando la posibilidad de la asociación FTCM y PRP ser el mejor tratamiento (14).

Vaz et al (21) en 2010 aplicaron un centrifugado osteogénico de la $\mathrm{MO}$ en fracturas experimentales de fíbulas de conejos y observaron un aumento promedio en la densidad mineral ósea de los callos de $40.3 \%$ y de la cantidad relativa de tejido óseo en $9.4 \%$, sin aumento considerable en las cantidades relativas de cartílago o fibrosis. El autor considera que el centrifugado favoreció la consolidación ósea con mejora cualitativa del callo óseo.

Kraus y Kirker-Head (19) en 2006 generaron un defecto en un de $21 \mathrm{~mm}$ en el fémur de perros y lo fijaron con placa para tener un modelo de no unión ósea. Tras 15 días de la creación del defecto, CTM autólogas de la MO fueron colectadas, aisladas y cultivadas y asociadas a un cilindro de hidroxiapatita e implantadas en el fémur. Hubo estímulo de formación ósea, con formación de hueso nuevo en el área adyacente al implante, infiltrándose en el hueso receptor.

Barros et al (22) en 2011 trataron fallas de segmento total del radio de conejos con $\mathrm{MO}$ integral o MO centrifugada aplicadas por vía percutánea. La aplicación por vía percutánea se mostró un método sencillo, con mínimo trauma a los tejidos, no introduciendo tejido desvitalizado para de esta forma reducir el riesgo de infección y de interferencia en la reparación ósea. La evaluación radiográfica de los miembros operados, realizadas el día del injerto y una semana después, demostró la eficiencia de la aplicación de la MO y su participación en la formación de hueso.

Investigadores evaluaron el potencial de cicatrización del alginato de calcio asociado a las CTM de la medula ósea cultivadas y diferenciadas en células osteogénicas en defectos óseos cranianos de ovejas. Tras seis semanas, se observó crecimiento óseo considerable en el grupo en que fueron utilizadas CTM en comparación con el grupo control, el cual recibió solamente alginato de calcio. Tras 18 semanas hubo reparación casi completa del 
MSCs of bone marrow grown and differentiated into osteogenic cells in cranial bone defects in sheep. After six weeks, it was observed considerable bone growth in the group in which MSCs were used compared with the control group, which received only calcium alginate. After 18 weeks there was almost total reparation in the experimental group when evaluated by computed tomography (23).

Contribution of stem cells in the healing of bone grafts. As the healing of a cortical bone graft passes through a critical period during the incorporation, in which the graft is gradually absorbed for later formation of new bone, becoming weak and vulnerable to rupture (4), one of the resources used by orthopedic surgeons to avoid complications is the application of osteosynthesis material that enhances the stability of the interfaces receptor-graft (24). However, giving up adjuvants to accelerate the healing process to decrease the fracture risk is extremely welcome. The MSCs applications in bone grafts has been used precisely for this purpose, because in addition to their ability to differentiate into bone cells, they are also capable of recruiting FCs to the fracture focus, thus stimulating the additional recruitment of other MSCs present in bone tissue and enhancing the bone repair process (6). These authors state that there are no doubts on their benefits, being BM the main obtaining source for use in bone grafts. Del Carlo et al (25) in 2007 compared the consolidation of cortical bone allografts of dogs associated with different adjuvants. At the group 1 (control) only the allograft was placed in the tibial defect. At the group 2, the graft-host interfaces were filled up only with autogenous bone graft. In group 3 it was associated with autogenous bone graft, the morphogenetic bone protein (MBP) and finally in group 4, it was associated the SC from BM with MBP. The precocity of radiodensity in the graft and the full integration of the interfaces were observed in greater intensity in groups 4,3.2 and 1, respectively. Microscopically, the largest bone formation took place, by the order in groups 4,2,3 and 1 . The authors concluded that the group with association of SC from BM with the MBP contributed to the precocity of the bone formation, resulting in osteogenesis and osteoinduction in the interfaces, respectively.

Gomes (26) in 2008 evaluated the bone healing of the autograft from the iliac crest associated with BM cellular therapy. Bone defects were created in the rabbits' jaw, and the control group treated only with the autograft from the iliac crest and the experimental group with the autograft associated with the mononuclear BM cells of autogenous of the femur. By the radiographic grupo experimental cuando fue evaluada por la tomografía computadorizada (23).

\section{Contribución de las células-madre en la} cicatrización de injertos óseos. Como la cicatrización de un injerto óseo cortical pasa por un período crítico durante la incorporación, en que el injerto es gradualmente absorbido para la posterior formación de hueso nuevo, haciéndose débil y vulnerable a la ruptura (4). Uno de los recursos utilizados por el ortopedista para evitar complicaciones es la aplicación de material de osteosíntesis que refuerza la estabilidad de las interfaces receptor-injerto (24). Adicionalmente utilizar adyuvantes que aceleren el proceso de cicatrización para disminuir el riesgo de fractura es muy benefico. La aplicación de CTM en injertos óseos viene siendo utilizada justamente con ese objetivo, pues además de su capacidad para diferenciarse en células óseas, también son capaces de reclutar FCs al foco de fractura; estimulando, así, el reclutamiento adicional de otras CTM presentes en el tejido óseo y potencializando el proceso de reparo óseo (6). Estos autores comentan que no hay dudas de sus beneficios, siendo la MO la fuente principal de obtención para uso en injertos óseos.

Del Carlo et al (25) en 2007 compararon la consolidación de aloinjertos óseos corticales de perros asociados a diferentes adyuvantes. En el grupo 1 (control) solamente el aloinjerto fue inserido en la falla tibial. En el grupo 2 se llenó las interfaces injerto-hospedero solamente con autoinjerto esponjoso. En el grupo 3 se asoció al autoinjerto esponjoso, la proteína ósea morfogenética (BMP) y por fin en el grupo 4, se asoció CT de la MO con BMP. La precocidad de la radiopacidad en el injerto y la integración completa de las interfaces fueron verificadas en mayor intensidad en los grupos 4, 3, 2 y 1 , respectivamente. Microscópicamente, la mayor formación de hueso ocurrió, por el orden en los grupos 4, 2, 3 y 1 . Los autores concluyeron que el grupo presentando asociación de las CT de la MO con la BMP contribuyó para la precocidad de la formación ósea, determinando osteogénesis y osteoinducción en las interfaces, respectivamente.

Gomes (26) en 2008 evaluó la cicatrización ósea del autoinjerto de la cresta ilíaca asociada a terapia celular de la MO. Defectos óseos fueron creados en la mandíbula de conejos, siendo el grupo control tratado solamente con el autoinjerto asociado a las células mononucleares de la MO autógena del fémur. Por el análisis radiográfico se observó un aumento gradual de la densidad ósea con $85.71 \%$ de los animales del grupo experimental y $42.85 \%$ del grupo 
analysis it was showed a gradual increase of bone density with $85.71 \%$ of the animals in the experimental group and $42.85 \%$ in the control group presenting bone bridge formation 28 days after surgery. In the histopathological analysis at 15 days, the grafts were easily visualized and the phagocytic cells activity was intense. Whereas at 30 days, its visualization was harder and when it was possible, only a remnant was noticed. Based on the results obtained the authors suggest that the addition of BM mononuclear cells favors the healing of the autograft in rabbits' mandibular defects.

$\mathrm{Li}$ and $\mathrm{Li}$ (27) in 2005 used MSC from bone marrow grown and differentiated into osteoblasts, associated with allogenic demineralized bone graft in the filling of rabbits' mandibular defects. Along the weeks, radiographic examinations were performed to evaluate the healing, being that in the twelfth week it was hardly seen the defect in the experimental group, which presented a density similar to that of the rabbits' mandibular bone. Whereas in the control group, at the portion below the defect it was still possible to see radiolucent areas.

Researchers carried out defects in mice's cranial vault, being that at the group 1 the same was rebuilt with bovine lyophilized bone and MSC and at the group 2 it was used only lyophilized bone. The lyophilized bone from group 1 was left on the cultivation plate 24 hours prior to the procedure. There was significant difference between the groups, being that from the point of view of histological regeneration the grafts containing MSCs showed better results when compared to those without combination with cells. The authors concluded that the use of MSCs could mean an improvement in the quality of bone grafts and an optimization in time for the integration of these grafts (28)

Pelegrine et al (29) in 2013 carried out bilateral defects in the parietal bone in five experimental groups $(n=6)$ and a control group (=3) of rabbits. In the $\mathrm{G} 1$ defects were covered only by a bone substitute of bovine origin (Bio Oss), the G2 the defects were filled by Bio Oss and a fresh bone marrow aspirate, in G3 by Bio Oss and the BM mononuclear fraction, the G4 by Bio Oss and MSC from BM and the G5 by Bio Oss and MSM from adipose tissue. One of the defects of each animal was covered by a collagenous membrane and the other was maintained without coating. After two months, the animals underwent euthanasia and their parietal bones were analyzed through histomorphometry. The authors could observe that in the control group there was no bone formation and the other groups the cellular control presentando formación de puente óseo 28 días después de la cirugía. Al análisis histopatológico, a los 15 días, los injertos eran fácilmente visualizados y la actividad de las células fagocitarias era intensa. Ya a los 30 días, su visualización era más difícil y cuando fue posible, solamente un resquicio era notado. Con base en los resultados obtenidos los autores sugieren que la adición de células mononucleares de la MO favorece la cicatrización del autoinjerto en defectos mandibulares de conejos.

Li y Li (27) en 2005 utilizaron CRM de la medula ósea cultivadas y diferenciadas en osteoblastos, asociadas a injerto óseo alógeno desmineralizado en el llenado de falla mandibular de conejos. Al transcurso de las semanas, exámenes radiográficos fueron realizados para evaluar la cicatrización, siendo que en la décima segunda semana difícilmente se observaba la falla en el grupo experimental, el cual presentaba densidad similar a la del hueso mandibular del conejo. Ya en el grupo control, en la porción debajo de la falla aún era posible observar regiones radio lúcida.

Investigadores provocaron defectos en el casquete craneano de ratones, siendo que en el grupo 1 se reconstituyó la misma con hueso liofilizado bovino y CTM y en el grupo 2 solamente hueso liofilizado. El hueso liofilizado del grupo 1 era mantenido en placa de cultivo 24 horas antes del procedimiento. Hubo diferencia significativa entre los grupos, siendo que del punto de vista de regeneración histológica los injertos conteniendo CTM indiferenciadas presentaron resultados mejores, cuando fueron comparados con aquellos sin combinación con células. Los autores concluyeron que el empleo de CTM puede significar una mejora en la calidad de los injertos óseos y una optimización en el tiempo para la integración de esos injertos (28).

Pelegrine et al (29) en 2013 provocaron defectos bilaterales en el hueso parietal en cinco grupos experimentales $(n=6)$ y un grupo control $(=3)$ de conejos. En el G1 los defectos fueron cubiertos solamente por un sustituto óseo de origen bovino (Bio Oss), en el G2 los defectos fueron rellenados por Bio Oss y un aspirado de medula ósea fresca, en el G3 por Bio Oss y fracción mononuclear de la MO, en el G4 por Bio Oss y CTM de la MO y en el G5 por Bio Oss y CTM del tejido adiposo. Uno de los defectos de cada animal fue recubierto por una membrana colágena y el otro fue mantenido sin recubrimiento. Tras dos meses, los animales sufrieron eutanasia y sus huesos parietales fueron analizados por histomorfometría. Los autores pudieron observar que en el grupo control no hubo 
therapy maximized the regenerative results through an osteoconductive biomaterial. The concentration bone marrow cells, in addition to being less complex than techniques of cell culture, presented regenerative important results, seeming to represent a methodology clinically plausible.

De Mello and Oliveira et al (30) in 2014 created bone defects in the rabbits' skull, which were reconstructed with titanium cylinders. Subsequently, the animals were divided into two groups: group 1 had the cylinder filled with xenograft and the group 2 with xenograft associated with mononuclear fraction of the bone marrow. After two months the animals were subjected to euthanasia and the cylinders along with the parietal bone were analyzed regarding the bone volume formed inside the cylinders and histophotometry. Once more the groups where there was the association of the mononuclear fraction of the bone marrow showed superiority in the improvement of the bone healing and the bone integration.

Long et al (31) in 2014 grew MSCs from BM around cortical allografts and applied in femoral defects in a group of mice. At the other group, the allograft was applied without the cells. With the radiographic evaluations, histological cuts, and biomechanical tests in up to six weeks after the surgery, the authors concluded that the allograft is associated to the MSC induced the increase of bone callus formation, as well as the osteointegration host-graft. The biomechanical tests also exhibited a significant increase at the structural and functional proprieties of the femurs grafted with the cells. Finally, the allografts associated with MSC exhibited a better osteogenecity during the critical defect repairs, demonstrating the viability of this treatment to accelerate the healing process of bone grafts. Conclusions

Most of the studies performed so far have shown promising results regarding the application of adult stem cells in the fractures healing and bone grafts. Thanks to its osteogenic potential the healing time decreases and this is reflected in a lower risk of complications in the postoperative period, such as non-union and the graft weakening, with subsequent fracture.

The obtaining of stem cells from adipose tissue is an alternative to bone marrow with some advantages, such as ease of collection, abundance of content and results in less painful process. In the years from 2007 to 2010, at LATECER mononuclear fraction of BM and SVF from adipose tissue were used, however, from formación ósea y en los otros grupos la terapia celular maximizó los resultados regenerativos, auxiliados por un biomaterial osteoconductor. La concentración de células medulares, además, de ser menos complejas que técnicas de cultivo celular, presentaron resultados regenerativos importantes, pareciendo representar una metodología clínicamente plausible.

De Mello y Oliveira et al (20) en 2014 crearon defectos óseos en el cráneo de conejos, los cuales fueron reconstruidos con cilindros de titanio. Posteriormente, los animales fueron divididos en dos grupos: el grupo 1 tuvo el cilindro rellenado con xenoinjerto y el grupo 2 con xenoinjerto asociado a la fracción mononuclear de la medula ósea. Tras dos meses los animales fueron sometidos a eutanasia y los cilindros juntamente con el hueso parietal fueron analizados en cuanto al volumen óseo formado dentro de los cilindros e histomorfometría. Una vez más el grupo donde hubo la asociación de la fracción mononuclear de la medula ósea demostró superioridad en la mejora de la cicatrización ósea y osteointegración.

Long et al (31) en 2014 cultivaron CTM de la MO alrededor de aloinjertos corticales y lo aplicaron en defectos femorales en un grupo de ratones. En el otro grupo, el aloinjerto fue aplicado sin las células. Con las evaluaciones radiográficas, cortes histológicos y pruebas biomecánicas en hasta seis semanas después de la cirugía, los autores concluyeron que el aloinjerto asociado a las CTM indujo el aumento de la formación de callo óseo, bien como la osteointegración hospedero-injerto. Las pruebas biomecánicas también mostraron un aumento significativo en las propiedades estructurales y funcionales de los fémures injertados con las células. Por fin, los aloinjertos asociados a las CTM exhibieron una osteogenicidad mejorada durante la reparación crítica de los defectos; demostrando la viabilidad de este tratamiento para acelerar el proceso de cicatrización de injertos óseos.

En conclusión la mayoría de los estudios realizados hasta el momento han mostrado resultados promisorios relacionados con la aplicación de células-madre adultas en la cicatrización de fracturas y de injertos óseos. Debido a su potencial osteogénico el tiempo de cicatrización disminuye y eso se refleja en menor riesgo de complicaciones en el período pos-operatorio, como no unión y discapacidad del injerto, con posterior fractura.

La obtención de células-madre a partir del tejido adiposo es una alternativa a la medula ósea con algunas ventajas, como la facilidad de colecta, 
2011 on researches were begun using cells cultured from tissues that offer lower morbidity in the collection harvest, such as adipose tissue and dental pulp.

The possibility of using not only the total fractions of tissues stem cells, but also their expansion in culture and differentiation allow their application according to the reality of each surgical center, being that regardless of the procedure used, the healing shall always be benefited. abundancia de contenido y resulta un proceso menos doloroso. En los años de 2007 a 2010 fueron utilizados en el LATECER fracción celular mononuclear de la MO y FVE del tejido adiposo; sin embargo, a partir de 2011 se iniciaron las pesquisas utilizando células cultivadas de tejidos que ofrecen menor anormalidad en la colecta, como tejido adiposo y pulpa dental.

La posibilidad de utilizar las fracciones totales de las células-madre de los tejidos, cuanto a su expansión en cultivos y diferenciación permiten su aplicación de acuerdo con la realidad de cada centro quirúrgico, siendo que independientemente del procesamiento realizado, la cicatrización siempre podrá ser beneficiada.

\section{REFERENCES}

1. Nardi NB. Células-tronco: fatos, ficção e futuro. Genética na escola 2007; 2(2):25-29.

2. Cristante AF, Narazaki DK. Avanços no uso de células-tronco em ortopedia. Rev Bras Ortop 2011; 46(4):359-367.

3. Monteiro BS, Argôlo-Neto NM, Del Carlo RJ. Terapia celular em reparação óssea - aplicação clínica de células tronco mesenquimais. Ciênc Vet Trop 2008; 11(supl 2):95-100.

4. Slatter D. Manual de Cirurgia de Pequenos Animais 3 ed. Barueri: Manole; 2007.

5. Dias MIR, Souza CMP, Carvalho PMP, Lempek MR, Viegas CAA, Azevedo JMT. Enxertos e substitutos ósseos em cirurgia ortopédica reconstrutiva nos animais de companhia uma breve revisão. Rev Bras Med Vet 2013; 35(4):339-350.

6. Pagliosa GM, Alves GES. Considerações sobre obtenção e uso do plasma rico em plaquetas e das células mesenquimais indiferenciadas em enxertos ósseos. Cienc Rural 2007; 37(4):1202-1205.

7. Yarak S, Okamoto OK, Células-tronco derivadas de tecido adiposo humano: desafios atuais e perspectivas clínicas. An Bras Dermatol 2010; 85(5):647-656.

8. Monteiro BS, Argôlo-Neto NM, Del Carlo RJ. Células-tronco mesenquimais. Cienc Rural 2010; 40(1):238-245.
9. Viscondi ES, Dias FGG, Rocha TASS, Pereira LF, Dias LGGG. Células-tronco em pequenos animais. Enciclopédia Biosfera 2013; 9(16):635-647.

10. Pinto Filho $S T L$, Treichel TLE, Aramburú Junior JS, Rosa MB, Dalmolin F, Brun MV et al. Células-tronco mesenquimais adultas: Características e aplicações experimentais em animais. Vet Zootec 2013; 20:49-59.

11. Salem HK, Thiemermann C. Mesenchymal stromal cells: current understanding and clinical status. Stem Cells 2010; 28(3):585-596.

12. Tognoli GK, Olsson DC, Martins DB, Santos Júnior ED, Salbego FZ, Oliveira GK et. Transplante autólogo de células mononucleares da medula óssea em úlcera de córnea experimental em cães. Cienc Rural 2009; 39(1):148-155.

13. Mizuno H. Adipose-derived stem cells for tissue repair and regeneration: Ten years of research and a literature review. J Nippon Med Sch 2009; 76(2):56-66.

14. Barbosa ALT, Schossler JE, Raiser AG, Serafini GMC, Treichel TLE, Libardoni $\mathrm{RN}$, et al. Células-tronco mononucleares associadas ao plasma rico em plaquetas na consolidação de falha óssea no cão. Estudo piloto. Arq Bras Med Vet Zootec 2014; 66(6): 1718-1726. 
15. Maia L, De Vita B, Moraes CN, Destro FC, Landim-Alvarenga FC, Amorim RM. Considerações sobre a obtenção, processamento, caracterização e aplicação terapêutica das células-tronco mesenquimais em medicina equina. Vet Zootec 2013; 20(3):359-373.

16. Bertine $M A H$, Araújo FS. Biologia e uso clínico das células-tronco mesenquimais: uma revisão concisa. Investigação 2009; 9(2/3):105-110.

17. Bydlowski SP, Debes AA, Maselli LMF, Janz FL. Características biológicas das célulastronco mesenquimais. Rev Bras Hematol Hemoter 2009; 31(sup1):25-35.

18. Treichel TLE, Cunha MGMCM, Cunha JPMCM, Santos Júnior EB, Leme Júnior PTO, Costa MM et al. Transplante de fração total de células mononucleares ou fração vascular estromal associada à membrana celulósica em feridas cutâneas experimentais de coelhos. Braz J Vet Res Anim Sci 2011 48(1):62-72.

19. Kraus KH, Kirker-Head C. Mesenchymal stem cells and bone regeneration. Vet Surg $2006 ; 35: 232-242$.

20. Oliveira GK, Raiser AG, Olsson D, Salbego $F Z$, Martins DB, Dezengrine R et al. Célulastronco mononucleares autólogas e proteína óssea morfogenética na cicatrização de defeitos tibiais experimentalmente induzidos em cão. Arq Bras Med Vet Zootec 2010; 62(1):72-79.

21. Vaz CES, Guarniero R, Santana, PJ. Avaliação do Centrifugado Osteogênico de Medula Óssea na Consolidação de Fraturas em Coelhos. Acta Ortop Bras 2010; $18(6): 321-326$.

22. Barros SVSG, Del Carlo RJ, Vargas MI, Galvão SR, Filho AM. Auto-enxerto percutâneo de medula óssea em coelhos.I. Coleta, preparo e aplicação. Cienc Rural 2001; 31(6):1013-1018.

23. Shang Q, Wang Z, Liu W, Shi Y, Cui L, Cao $Y$. Tissue-engineered bone repair of sheep cranial defects with autologous bone marrow stromal cells. J Craniofac Surg 2001; 12(6):586-593.
24. Dias RMF, Carvalhais P, Matos P, Judas F. Aloenxertos ósseos na osteossíntese de fracturas traumáticas. RPOT 2008; 16:31-42.

25. Del Carlo RJ, Pinheiro LCP, Monteiro BS, Silva PSA, Viana VW. Integração de aloenxertos ósseos corticais associados ou não a células-tronco da medula óssea, proteína óssea morfogenética (bmp) e autoenxerto esponjoso em cães. Vet Zootec 2007; 14(2):204-215.

26. Gomes C. Avaliação da cicatrização óssea em falha mandibular com auto-enxerto ósseo associado a suspensão celular de medula óssea autógena: estudo experimental. Acta Sci Vet 2008; 36(3):331-332.

27. Li Z, Li ZB. Repair of mandible defect with tissue engineering bone in rabbits. ANZ J Surg 2005; 75:1017-1021.

28. Portinho $\mathrm{CP}$, Collares MVM, Silva FH, Nardi NB, Pinto RA, Siqueira E. Reconstrução de calota craniana com células-tronco mesenquimais indiferenciadas: estudo experimental. Rev Soc Bras Cir Plást 2006; 21(3):161-165.

29. Pelegrine $A A$, de Melo e Oliveira $R$, Zimmermann A, Aloise AC, Ferreira LM. Terapia celular em regeneração óssea. Avaliação histomorfométrica de diferentes metodologias. ImplantNews 2013; 10(4):428-36.

30. De Mello e Oliveira R, Pelegrine AA, Aloise AC, Ferreira LM. Xenograft impregnated with bone marrow mononuclear fraction for appositional bone regeneration in rabbit calvaria: a clinical and histomorphometric study. Int J Oral Maxillofac Implants 2014; 29(4):962-968.

31. Long T, Zhu Z, Awad HA, Schwarz EM, Hilton $M J$, Dong $Y$. The effect of mesenchymal stem cell sheets on structural allograft healing of critical sized femoral defects in mice. Biomaterials 2014; 35:2752-2759. 